\title{
Genetic diversity and structure of the tree Enterolobium contortisiliquum (Fabaceae) associated with remnants of a seasonally dry tropical forest
}

\author{
Patrícia de Abreu Moreira ${ }^{\mathrm{a}, *}$, Murilo Malveira Brandão ${ }^{\mathrm{b}}$, Natalia Hayashida de Araujo ${ }^{\mathrm{b}}$, \\ Dario Alves de Oliveira ${ }^{\mathrm{b}}$, G. Wilson Fernandes ${ }^{\mathrm{c}}$ \\ a Departamento de Biodiversidade, Evolução e Meio Ambiente, Instituto de Ciências Exatas e Biológicas, Universidade Federal de Ouro Preto, CEP $35400-000$ \\ Ouro Preto, MG, Brazil \\ ${ }^{\mathrm{b}}$ Laboratório de Bioprospecção e Recursos Genéticos, DBG, Universidade Estadual de Montes Claros, CEP $39401-089$ Montes Claros, MG, Brazil

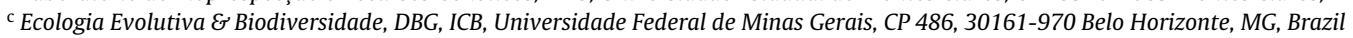

\section{A R T I C L E I N F O}

\section{Article history:}

Received 20 January 2014

Received in revised form 6 October 2014

Accepted 15 October 2014

Edited by Bohumil Mandák

Available online 1 November 2014

\section{Keywords:}

Genetic structure

ISSR

Conservation

Dry forest

Brazil

\begin{abstract}
A B S T R A C T
Fragmentation of tropical forests is one of the major threats to biodiversity and viable natural populations. Brazilian seasonally dry tropical forests (SDTF) are endangered because of human occupation, conversion of lands to agriculture and high deforestation rates in these fertile soils. Enterolobium contortisiliquum has been removed from SDTF natural areas due to the advance of cattle grazing and agriculture in Brazilian SDTFs. To aid conservation efforts of this species we used molecular markers to study the genetic diversity and population structure of $E$. contortisiliquum in Brazilian SDTF remnants. A total of 263 individuals in 13 forest patches were analyzed with 103 ISSR fragments. In spite of being found scattered among the SDTF patches, E. contortisiliquum populations exhibited high genetic diversity (mean Shannon's index of diversity $=0.384$; mean genetic diversity $=0.280$ ) and genetic divergence between populations was detected $\left(\Phi_{\mathrm{ST}}=0.155, p<0.0001\right)$. UPGMA dendrogram, principal coordinate analysis and Bayesian analysis showed that E. contortisiliquum populations were clustered into three groups that were not related to geographic distance $(r=0.119, p=0.197)$. However, these populations are spatially structured into groups distributed in the West, Central and East of the study area. This genetic structure may be related with landscape and both the Espinhaço Range and São Francisco River may act as a partial geographic barrier limiting the gene flow. Because the highest rates of genetic diversity were found outside of conservation units, we propose the creation of protected areas in different geographic regions that include E. contortisiliquum populations from different genetic clusters.
\end{abstract}

(C) 2014 Elsevier GmbH. All rights reserved.

\section{Introduction}

Ongoing fragmentation of tropical forests is one of the major threats to biodiversity conservation and viable natural populations (Saunders et al., 1991). This is especially worrisome for seasonally dry tropical forests (SDTF) which are considered to be one of the most endangered tropical ecosystems (Janzen, 1988; Miles et al., 2006; Steininger et al., 2001). SDTFs occur in regions characterized by pronounced seasonality in rainfall distribution, where precipitation is $<1600 \mathrm{~mm} / \mathrm{yr}$ with several months of drought and a period of at least five or six months receiving < $100 \mathrm{~mm}$ (Gentry, 1995;

\footnotetext{
* Corresponding author. Tel.: +55 3135591214.

E-mail addresses: patriciadabreu@yahoo.com.br, pattyabreu13@gmail.com (P.A. Moreira).
}

Graham and Dilcher, 1995). SDTFs are dominated by deciduous trees with a more or less continuous canopy (Mooney et al., 1995; Sánchez-Azofeifa et al., 2005). The most dominant plant families are Fabaceae and Bignoniaceae (Gentry, 1995; Mayle, 2004).

The tropical dry forests exhibit a disjunct distribution throughout the Neotropics (Pennington et al., 2006). The currently discontinuous distribution of SDTFs represent the remnants of a more widespread and contiguous formation during the Pleistocene that formed the "Pleistocenic Arc" (Prado, 2000; Prado and Gibbs, 1993). The largest areas of SDTFs occur in South America, specifically in Brazil (Pennington et al., 2006), where they represent 3.21\% of its territory (Sevilha et al., 2004). As in other localities, Brazilian SDTFs are associated with fertile soils with a moderate to high $\mathrm{pH}$ and high nutrient content (Espírito-Santo et al., 2009; Pennington et al., 2006). Hence, the Brazilian SDTFs patches are now under severe threats because of human occupation, conversion of lands 
to agriculture and high deforestation rates in these fertile soils (Espírito-Santo et al., 2009).

Studies of fragmentation effects in plants have shown that forest loss may have negative consequences on reproduction, gene flow and genetic diversity (Aguilar et al., 2006, 2008; Ledig, 1992; Lowe et al., 2005; Templeton et al., 1990). Thus, trees in remnant fragments could alter mating patterns, increase inbreeding and decrease genetic diversity (Aguilar et al., 2008). Therefore, the disjunct distribution of Brazilian SDTF and its alteration by human activities may decrease the genetic diversity of plant species.

Enterolobium contortisiliquum (Vell.) Morong is a Neotropical tree species considered as a SDTF specialist (Särkinen et al., 2011) and it was used to define the Pleistocenic Arc (Prado, 2000; Prado and Gibbs, 1993). The species flowers during a short period, September and October, when it is leafless, while fruits ripen between June and July (P.A. Moreira, personal observations). The mature fruits and seeds of $E$. contortisiliquum resemble other Enterolobium species. As with E. cyclocarpum, its fruits are smooth, shiny, indehiscent and deep brown (Rocha and Aguilar, 2001a) and the seeds are hard, ovoid and brown (Janzen, 1982). Recently, it was discovered that a proteinase inhibitor of this species, Enterolobium contortisiliquum trypsin inhibitor (EcTI), inhibited the invasion of gastric cancer cells, providing a possible candidate for therapy against tumors (Paula et al., 2012).

This tree has been removed from natural areas owing to the advance of cattle grazing and agriculture in Brazilian SDTFs due to its poisonous fruits. The ingestion of $E$. contortisiliquum pods is harmful to cattle, causing photosensitivity reactions and spontaneous abortion (Bonel-Raposo et al., 2008; Costa et al., 2009). As a result many farmers have cut these trees near their ranches as fruiting of $E$. contortisiliquum occurs during the dry season and coincides with low forage availability. This logging has lead to populations of $E$. contortisiliquum becoming vulnerable in the disjunct SDTF matrix. Hence, understanding of the effects of fragmentation and selective logging on this tree is urgently needed for its conservation.

To better conserve this species we used molecular markers to study the genetic diversity and structure in populations of
Table 1

Geographical location and sampling details of Enterolobium contortisiliquum populations studied.

\begin{tabular}{lllc}
\hline Populations & Population code & Latitude/longitude & Sample size \\
\hline Unaí & UNA & $16^{\circ} 19^{\prime} \mathrm{S} 46^{\circ} 55^{\prime} \mathrm{W}$ & 20 \\
Paracatu & PAR & $17^{\circ} 06^{\prime} \mathrm{S} 46^{\circ} 50^{\prime} \mathrm{W}$ & 20 \\
João Pinheiro & JOP & $17^{\circ} 44^{\prime} \mathrm{S} 46^{\circ} 11^{\prime} \mathrm{W}$ & 16 \\
Felício dos Santos & FES & $18^{\circ} 04 \mathrm{~S}^{\circ} 42^{\prime} \mathrm{W}$ & 20 \\
Gouveia & GOU & $18^{\circ} 37^{\prime} \mathrm{S} 44^{\circ} 01^{\prime} \mathrm{W}$ & 22 \\
Buenópolis & BUE & $17^{\circ} 52^{\prime} \mathrm{S} 44^{\circ} 10^{\prime} \mathrm{W}$ & 20 \\
Manga & MAN & $14^{\circ} 50^{\prime} \mathrm{S} 43^{\circ} 57^{\prime} \mathrm{W}$ & 21 \\
Itacarambi & ITA & $15^{\circ} 10^{\prime} \mathrm{S} 44^{\circ} 12^{\prime} \mathrm{W}$ & 20 \\
Verdelândia & VER & $15^{\circ} 34^{\prime} \mathrm{S} 43^{\circ} 35^{\prime} \mathrm{W}$ & 15 \\
Jequitaí & JEQ & $17^{\circ} 15^{\prime} \mathrm{S} 44^{\circ} 27^{\prime} \mathrm{W}$ & 20 \\
Várzea da Palma & VAR & $17^{\circ} 34^{\prime} \mathrm{S} 44^{\circ} 44^{\prime} \mathrm{W}$ & 29 \\
Beltrão & $\mathrm{BEL}$ & $18^{\circ} 22^{\prime} \mathrm{S} 44^{\circ} 29^{\prime} \mathrm{W}$ & 20 \\
Montes Claros & MOC & & 20 \\
& & & $21^{\prime} \mathrm{S} 43^{\circ} 56^{\prime} \mathrm{W}$ \\
Total & & & 26 \\
\hline
\end{tabular}

E. contortisiliquum in Brazilian SDTF patches. By using inter simple sequence repeats (ISSRs) we addressed the following questions: (1) What is the level of genetic diversity in E. contortisiliquum, in selected Brazilian SDTF patches? (2) How is the genetic variation of this species structured among these patches? and (3) Are there geographic barriers in the landscape that limited genetic distribution between populations along time?

\section{Materials and methods}

\section{Plant materials sampling}

Enterolobium contortisiliquum is a common species in the Brazilian SDTFs, with a density ranging from three to eight individuals per hectare (Oliveira-Filho, 2006). From 15 to 29 adult trees were sampled in 13 Brazilian SDTF patches, totaling 263 individuals (Fig. 1, Table 1). Expanded leaves were collected from all individual trees and stored on silica gel until DNA extractions were carried out. Each SDTF remnant was treated as a population:

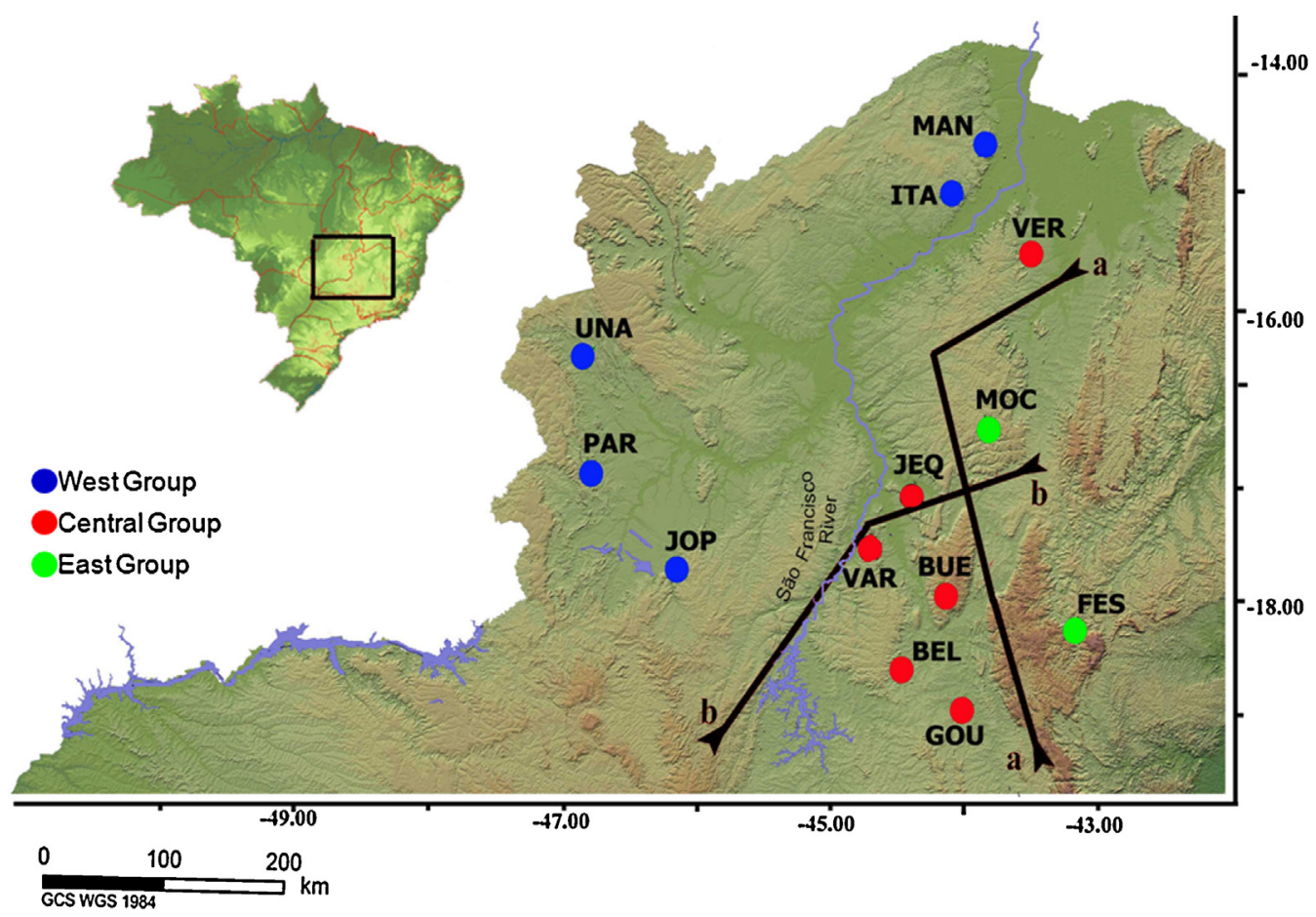

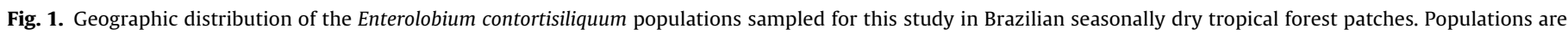
identified according to spatial genetic groups established by STRUCTURE (identified in the legend). Black lines indicate two barriers among populations. 
Table 2

ISSR primers used for PCR amplifications of Enterolobium contortisiliquum.

\begin{tabular}{lllr}
\hline Primer name & Sequence $\left(5^{\prime}-3^{\prime}\right)^{\mathrm{a}}$ & $T_{\mathrm{a}}\left({ }^{\circ} \mathrm{C}\right)^{\mathrm{b}}$ & $N^{\mathrm{c}}$ \\
\hline John & $(\mathrm{AG})_{7} \mathrm{YC}$ & 47 & 10 \\
Manny & $(\mathrm{CAC})_{4} \mathrm{RC}$ & 47 & 7 \\
Mao & $(\mathrm{CTC})_{4} \mathrm{RC}$ & 47 & 6 \\
Terry & $(\mathrm{GTG})_{3} \mathrm{GGTGRC}$ & 46 & 14 \\
UBC810 & $(\mathrm{GA})_{8} \mathrm{~T}$ & 47 & 9 \\
UBC827 & $(\mathrm{AC})_{8} \mathrm{G}$ & 47 & 10 \\
UBC840 & $(\mathrm{GA})_{8} \mathrm{YT}$ & 47 & 18 \\
UBC879 & $(\mathrm{CTTCA})_{3}$ & 47 & 6 \\
UBC880 & GGAGAGGAGAGGAGA & 47 & 11 \\
UBC899 & $(\mathrm{CA})_{6} \mathrm{RG}$ & 47 & 12 \\
Total & & & 103
\end{tabular}

a $\mathrm{Y}=\mathrm{C}$ or $\mathrm{T} ; \mathrm{R}=\mathrm{A}$ or $\mathrm{G}$.

b Annealing temperature of primers.

c $N$ =number of fragments for each primer. All fragments were polymorphic when considering all populations.

Unaí (UNA), Paracatu (PAR), João Pinheiro (JOP), Felício dos Santos (FES), Gouveia (GOU), Buenópolis (BUE), Manga (MAN), Itacarambi (ITA), Verdelândia (VER), Jequitaí (JEQ), Várzea da Palma (VAR), Beltrão (BEL) and Montes Claros (MOC).

\section{DNA extraction and ISSR amplification}

Genomic DNA extraction followed the standard CTAB procedure (Doyle and Doyle, 1987). DNA integrity was checked by electrophoresis on $1.0 \%$ agarose gels with $1 \times$ TBE buffer, stained with ethidium bromide and photographed under UV light. The DNA obtained was diluted in ultrapure water up to final concentration of $5.0 \mathrm{ng} / \mu \mathrm{L}$ prior to PCR amplification.

An initial screening of 20 primers was undertaken for ISSR analysis. ISSR amplifications were performed in a $15 \mu \mathrm{L}$ volume containing $20.0 \mathrm{ng}$ of template DNA, PCR buffer $(50 \mathrm{~mm} \mathrm{KCl}, 10 \mathrm{~mm}$, Tris- $\mathrm{HCl} \mathrm{pH} 8.4,0.1 \%$ Triton X-100, Phoneutria), $0.50 \mathrm{mM} \mathrm{MgCl}_{2}$, $0.25 \mu \mathrm{g}$ of BSA, $250 \mu \mathrm{M}$ of each dNTP, $10.0 \mu \mathrm{M}$ of primer and 1 unit of Taq DNA polymerase (Phoneutria). Amplifications were performed using Veriti thermal controller (Life Technologies) under the following conditions: $94^{\circ} \mathrm{C}$ for $4 \mathrm{~min}$ (one cycle); $94^{\circ} \mathrm{C}$ for $1 \mathrm{~min}$, 46 or $47^{\circ} \mathrm{C}$ for $1 \mathrm{~min}$ (according to each primer, Table 2 ), $72^{\circ} \mathrm{C}$ for $1 \mathrm{~min}$ ( 37 cycles); and $72^{\circ} \mathrm{C}$ for $7 \mathrm{~min}$ (one cycle). A negative control, in which template DNA was omitted, was included in each PCR. ISSR amplified products were separated electrophoretically at a constant voltage of $100 \mathrm{~V}$ for $4 \mathrm{~h}$ in $1.5 \%$ agarose gels with $1 \mathrm{X}$ TBE buffer, stained with ethidium bromide and photographed under UV light (Gel Logic 212 Pro, Carestream). A 100-bp DNA ladder
(Fermentas) was used as a standard molecular weight to estimate the molecular size of the fragments.

\section{Data analysis}

Fragments amplified by ISSR were scored as present (1) or absent $(0)$ by manual verification to create a binary matrix. We assumed that amplified products of similar size using the same primer were homologous. To obtain consistent results, only data from clear and unambiguous bands were used for genetic analyses. Besides, the negative control was used in each agarose gel. Genetic diversity was measured by percentage of polymorphic loci $(P)$, the observed number of alleles $(\mathrm{Na})$, effective number of alleles $(\mathrm{Ne})$ and Shannon's index (I) (Lewontin, 1972), using the software PopGene v.1.32, which is designed for the analysis of dominant markers (Yeh et al., 1999), assuming Hardy-Weinberg equilibrium, $F_{\mathrm{IS}}=0$. The measures of genetic diversity included a Bayesian analysis (Holsinger et al., 2002), implemented in Hickory v1.0.4 (Holsinger and Lewis, 2005). We estimated Hs, which is analogous to Nei's (Nei, 1978) unbiased expected heterozygosity $\left(H_{\mathrm{E}}\right)$.

To estimate variance components and to partition the variation of the species within and among populations the Analysis of Molecular Variance (AMOVA) was performed using Arlequin v. 3.01 (Excoffier et al., 2005). The genetic structure was estimated by 10,000 permutations, assuming Hardy-Weinberg equilibrium, computing the distance matrix and proportion of the difference. Statistical significance of the variance proportion associated with the fixation index $\Phi_{\mathrm{ST}}$ was determined through permutation tests against a null distribution generated by the data.

The pairwise $\Theta^{\mathrm{B}}$ (a Bayesian analysis analogous to $F_{\mathrm{ST}}$ ) was obtained with $95 \%$ confidence intervals using the software Hickory v1.0.4 (Holsinger and Lewis, 2005) for all population pairs and used to construct a UPGMA (unweighted pair-group method with arithmetic averages) dendrogram using NTSYS v.2.2 (Rohlf, 2000) and to carry out a principal components analysis (PCA) with the software GenAlEx (Peakall and Smouse, 2006). To verify the isolation by distance a Mantel test was performed using PC-ORD v.6 (McCune and Mefford, 2011).

To determine the number of genetic clusters $(K)$, a Bayesian analysis of population structure was carried out with the software STRUCTURE 2.2. (Pritchard et al., 2007). A burn-in period of 100,000 generations and 100,000 steps of Markov Chain Monte Carlo simulations were used to estimate $\ln \operatorname{Pr}(X / K)$. We used the admixture model and the allele frequencies correlated model, without prior assumptions concerning the population. For each $K$ value, 10 runs were carried out to verify the consistency of the results. The average

Table 3

Genetic diversity parameters of 13 Enterolobium contortisiliquum populations detected by 10 ISSR molecular markers.

\begin{tabular}{|c|c|c|c|c|c|}
\hline Population & $N_{\mathrm{a}}$ & $N_{\mathrm{e}}$ & Hs & I & $P(\%)$ \\
\hline UNA & $1.952(0.215)$ & $1.571(0.341)$ & $0.339(0.007)$ & $0.492(0.206)$ & 95.19 \\
\hline PAR & $1.875(0.332)$ & $1.490(0.345)$ & $0.313(0.008)$ & $0.439(0.231)$ & 87.50 \\
\hline JOP & $1.883(0.323)$ & $1.527(0.361)$ & $0.316(0.009)$ & $0.454(0.237)$ & 79.81 \\
\hline FES & $1.711(0.455)$ & $1.463(0.388)$ & $0.254(0.013)$ & $0.390(0.283)$ & 71.15 \\
\hline GOU & $1.701(0.459)$ & $1.392(0.367)$ & $0.277(0.007)$ & $0.349(0.273)$ & 70.19 \\
\hline BUE & $1.721(0.451)$ & $1.342(0.366)$ & $0.255(0.011)$ & $0.315(0.264)$ & 72.12 \\
\hline MAN & $1.779(0.417)$ & $1.414(0.374)$ & $0.273(0.008)$ & $0.369(0.264)$ & 77.88 \\
\hline ITA & $1.740(0.441)$ & $1.472(0.398)$ & $0.272(0.008)$ & $0.392(0.283)$ & 74.04 \\
\hline VER & $1.659(0.476)$ & $1.397(0.393)$ & $0.241(0.008)$ & $0.338(0.289)$ & 61.54 \\
\hline JEQ & $1.798(0.403)$ & $1.431(0.366)$ & $0.259(0.009)$ & $0.385(0.258)$ & 79.81 \\
\hline VAR & $1.711(0.455)$ & $1.308(0.330)$ & $0.269(0.008)$ & $0.302(0.249)$ & 71.15 \\
\hline BEL & $1.769(0.423)$ & $1.406(0.355)$ & $0.279(0.011)$ & $0.370(0.258)$ & 76.92 \\
\hline MOC & $1.762(0.427)$ & $1.458(0.361)$ & $0.298(0.008)$ & $0.401(0.265)$ & 71.15 \\
\hline Mean & $1.774(0.405)$ & $1.436(0.361)$ & $0.280(0.003)$ & $0.384(0.258)$ & 76.03 \\
\hline Species & $2.000(0.000)$ & $1.589(0.299)$ & $0.370(0.005)$ & $0.519(0.162)$ & 98.78 \\
\hline
\end{tabular}

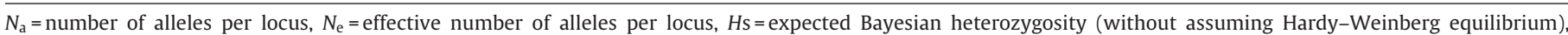
$I=$ Shannon's information index, $P=$ percentage of polymorphic bands. The values given in bracket are standard deviation. 
Table 4

Analysis of molecular variance (AMOVA) among and within Enterolobium contortisiliquum populations.

\begin{tabular}{|c|c|c|c|c|c|}
\hline Source of variation & d.f. & Sum of squares & Variance components & \% Total variance & $p$-Value \\
\hline Among populations & 12 & 139.54 & 0.512 & 15.54 & $<0.0001$ \\
\hline Within populations & 250 & 612.90 & 2.785 & 84.46 & $<0.0001$ \\
\hline \multicolumn{6}{|c|}{ Three groups according to Bayesian analysis } \\
\hline Among groups & 2 & 41.472 & 0.15387 & 4.58 & $<0.0001$ \\
\hline Among pops. within groups & 10 & 98.071 & 0.41777 & 12.44 & $<0.0001$ \\
\hline Within populations & 240 & 612.905 & 2.78593 & 82.97 & $<0.0001$ \\
\hline
\end{tabular}

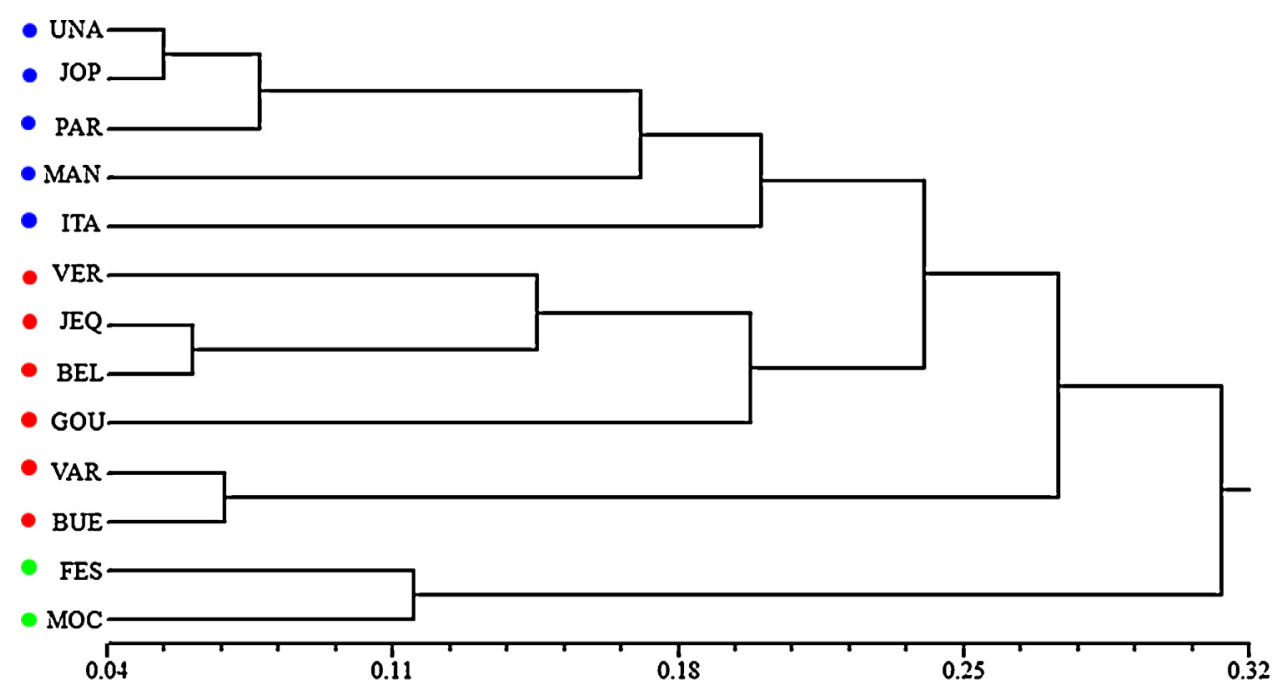

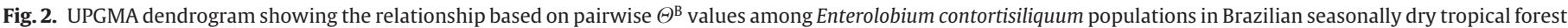
patches. Colored circles correspond to groups established by STRUCTURE (see Fig. 1 for legend).

of each likelihood value for $K$, 'log of probability' $[\operatorname{Ln} P(D)]$ through all runs were determined to infer the number of genetic clusters (Pritchard et al., 2000) and the statistic $\Delta K$ was estimated according to Evanno et al. (2005). Afterward, another AMOVA was performed according to the groups defined by this analysis.

To investigate genetic discontinuities in space Monmonier maximun difference algorithm (Monmonier, 1973) was implemented by the method of Delaunay triangulation using Barrier v.2.2 (Manni et al., 2004) as proposed by Legendre and Legendre (1998) and Manel et al. (2003).

\section{Results}

From 20 ISSR primers tested 10 were used and resulted in 103 clearly identifiable fragments (Table 2). Each primer amplified from six to 18 loci and all 103 scored bands were polymorphic at the species level and at population level the polymorphism ranged from 61.54 to $95.19 \%$ (Table 3). The average effective number of alleles per locus at the population level was 1.436 and 1.589 at the species level (Table 3 ). The genetic diversity (Hs) and Shannon's index $(I)$ were 0.370 and 0.519 , respectively, for E. contortisiliquum. Populations exhibited high genetic variability with mean $H$ s and $I$ equal to 0.280 and 0.384 , respectively. The VER population showed the lowest genetic diversity $(H s=0.241, I=0.338)$ while the UNA population showed the highest diversity $(H s=0.339, I=0.492)$.

Most of the variation was found among individuals within the same population (84.46\%) and only $15.54 \%$ of the variation occurred among populations (Table 4 ), which implies significantly high average fixation indices $\left(\Phi_{\mathrm{ST}}=0.155, p<0.0001\right)$. The $E$. contortisiliquum populations grouped into three main clusters (Fig. 2). The first cluster corresponded to UNA, PAR, JOP, ITA and MAN populations, the second cluster corresponded to VER, JEQ, BEL, VAR, BUE and GOU populations, and finally a third cluster corresponded to FES and MOC populations (Fig. 2). The pairwise $\Theta^{\mathrm{B}}$ ranged from 0.054 (between UNA and JOP) to 0.392 (between VAR and FES). The highest geographic distance was among FES and UNA populations which showed $\Theta^{\mathrm{B}}=0.231$ and the nearest distance was among VAR and JEQ populations which showed $\Theta^{\mathrm{B}}=0.271$ (Table 5). No significant correlation was found between geographical distance and genetic distance $(r=0.119, p=0.197)$.

PCA results were consistent with UPGMA dendrogram, grouping the same populations of UPGMA analysis. The first two axes explained most of the total variability (axis $1=39.95 \%$ and axis $2=26.30 \%$ ) (Fig. 3). The Bayesian approach showed that the number of genetic groups ( $K$ value) which best fit our data was $K=3$ (Fig. 4A). These groups are similar to the cluster of the UPGMA dendrogram and the three groups appear to be spatially structured with the first group located at the West, the second group located at the Central and the third group located at the East of the study area (Figs. 1 and 4B). In the AMOVA clustering the populations in

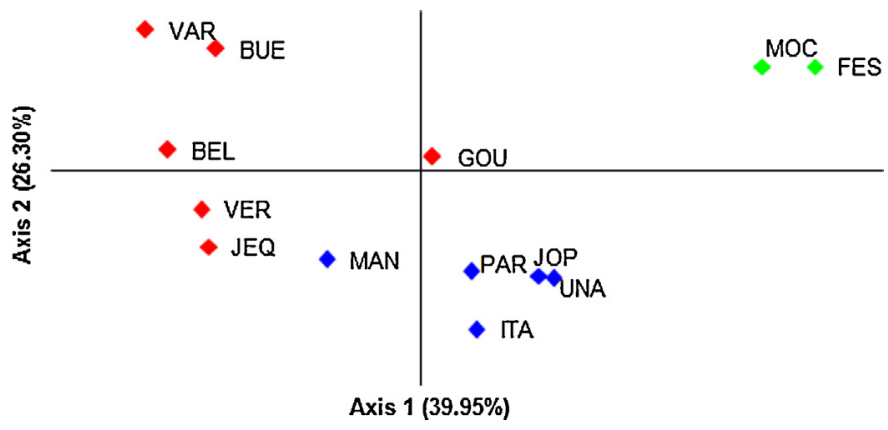

Fig. 3. Principal components analysis based on the Enterolobium contortisiliquum populations distance matrix. Axes 1 and 2 explained 39.95 and $26.30 \%$ of the variation, respectively. The colors of populations are according to groups established by STRUCTURE (see Fig. 1 for legend). 
Table 5

Matrix of population pairwise $\Theta^{\mathrm{B}}$ (below diagonal) and geographic distance in $\mathrm{km}$ (above diagonal) among 13 Enterolobium contortisiliquum populations.

\begin{tabular}{|c|c|c|c|c|c|c|c|c|c|c|c|c|c|}
\hline & UNA & PAR & JOP & ITA & MAN & VER & JEQ & BEL & VAR & BUE & GOU & FES & MOC \\
\hline UNA & - & 98 & 173 & 323 & 361 & 370 & 282 & 348 & 271 & 341 & 397 & 442 & 323 \\
\hline PAR & 0.073 & - & 102 & 356 & 398 & 386 & 253 & 287 & 225 & 295 & 340 & 402 & 312 \\
\hline JOP & 0.054 & 0.082 & - & 353 & 393 & 370 & 191 & 194 & 154 & 214 & 251 & 320 & 268 \\
\hline ITA & 0.194 & 0.224 & 0.133 & - & 49 & 79 & 234 & 358 & 272 & 297 & 380 & 337 & 170 \\
\hline MAN & 0.178 & 0.191 & 0.143 & 0.251 & - & 95 & 275 & 400 & 317 & 338 & 422 & 370 & 206 \\
\hline VER & 0.238 & 0.286 & 0.175 & 0.244 & 0.199 & - & 210 & 328 & 253 & 264 & 346 & 281 & 129 \\
\hline JEQ & 0.202 & 0.239 & 0.171 & 0.253 & 0.193 & 0.139 & - & 125 & 48 & 77 & 160 & 163 & 80 \\
\hline BEL & 0.271 & 0.259 & 0.215 & 0.326 & 0.228 & 0.152 & 0.061 & - & 93 & 67 & 56 & 141 & 196 \\
\hline VAR & 0.333 & 0.327 & 0.282 & 0.356 & 0.275 & 0.264 & 0.271 & 0.213 & - & 69 & 139 & 174 & 130 \\
\hline BUE & 0.279 & 0.298 & 0.243 & 0.333 & 0.246 & 0.163 & 0.229 & 0.185 & 0.069 & - & 88 & 106 & 132 \\
\hline GOU & 0.243 & 0.277 & 0.202 & 0.325 & 0.260 & 0.256 & 0.179 & 0.158 & 0.351 & 0.273 & - & 109 & 216 \\
\hline FES & 0.231 & 0.286 & 0.234 & 0.341 & 0.337 & 0.365 & 0.373 & 0.367 & 0.392 & 0.321 & 0.283 & - & 172 \\
\hline MOC & 0.237 & 0.248 & 0.238 & 0.341 & 0.332 & 0.341 & 0.347 & 0.339 & 0.368 & 0.310 & 0.261 & 0.115 & - \\
\hline
\end{tabular}

three groups (as suggested by Bayesian analysis) $4.58 \%$ of the total variation was found among the groups and $12.44 \%$ among populations within groups. Again, most of the variation was found among individuals within the same population (82.97\%) (Table 4).

The Delaunay triangulation, used to indicate the genetic discontinuities generated by barriers in the landscape, revealed that there are two key barriers (Fig. 1). The most intense (barrier 'a') separates populations belonging to the East group and the second (barrier ' $b$ ') separates most of the populations of the Central group (VAR, BUE, BEL and GOU).

\section{Discussion}

The ISSR markers revealed high levels of genetic diversity of Enterolobium contortisiliquum populations and this diversity is similar to other outcrossing species analyzed with another dominant molecular marker, RAPD which estimates are comparable with ISSR (Nybom, 2004). The high levels of genetic diversity found in E. contortisiliquum populations $(H s=0.280, I=0.384$ ) are similar to other Leguminosae species as Derris trifoliata (Wu et al., 2012) and Ormosia hosiei (Zhang et al., 2012) and is higher than for two other tree species from the Brazilian Cerrado, Dimorphandra mollis and Dimorphandra wilsonii (Souza and Lovato, 2010). The higher genetic diversity could be related to the pollination system of $E$. contortisiliquum and its long life cycle. Although the E. contortisiliquum mating system is still unknown, its congener E. cyclocarpum is predominantly outcrossed (Rocha and Aguilar, 2001b). We postulate that $E$. contortisiliquum could be an outcrossing species, which could explain the high levels of genetic diversity found. Besides, $E$. contortisiliquum flowers are apparently pollinated by moths, as $E$. cyclocarpum (Frankie et al., 2004; Hamrick and Apsit, 2004). Some moths are capable to fly long distances and can visit many trees in a foraging route (Haber and Frankie, 1989). In addition, moths can carry large pollen loads (Willmott and Búrquez, 1996) and cover great distances between consecutively visited plants (Linhart and Mendenhall, 1977). Furthermore, woody plants such as E. contortisiliquum may have persisted in remnant populations in SDTFs patches for a long time and our results probably reflect the historical genetic diversity of adult trees. In a recent meta-analysis it was confirmed that adults exhibited higher genetic variation than offspring in a fragmented landscape because of long term persistence in habitats (Vranckx et al., 2011).

The highest genetic diversities are registered in UNA, PAR and JOP populations ( mean $=0.323$ ), in the West of studied area, and the lowest in MAN, ITA and VER populations (mean $=0.262$ ), located in the upper São Francisco River. These results may be correlated with the conservation history of these areas. The West of the study area was occupied only in 18th century induced by exploration of gold. Before this, the north of the study area was fragmented and altered. The region of São Francisco River basin is highly disturbed and was occupied in the 17th century. Due to the high soil fertility this region has been receiving governmental financial support for agribusiness improvement and irrigation projects, such as Jaíba Irrigation project (see www.projetojaiba.com.br). Low genetic diversity was observed previously in Handroanthus ochraceus in the north of the studied region (Moreira et al., 2009; Moreira and Fernandes, 2013). Thus, late exploration of the UNA, PAR and JOP region may have contributed to the maintenance of large populations of E. contortisiliquum over generations which allowed greater gene flow among populations. Despite the current fragmentation of landscape caused by expansion of agricultural areas, these remnant populations maintain high genetic diversity. As a result, UNA, PAR and JOP populations are important reservoirs of genetic diversity of the species E. contortisiliquum and must be preserved. It is
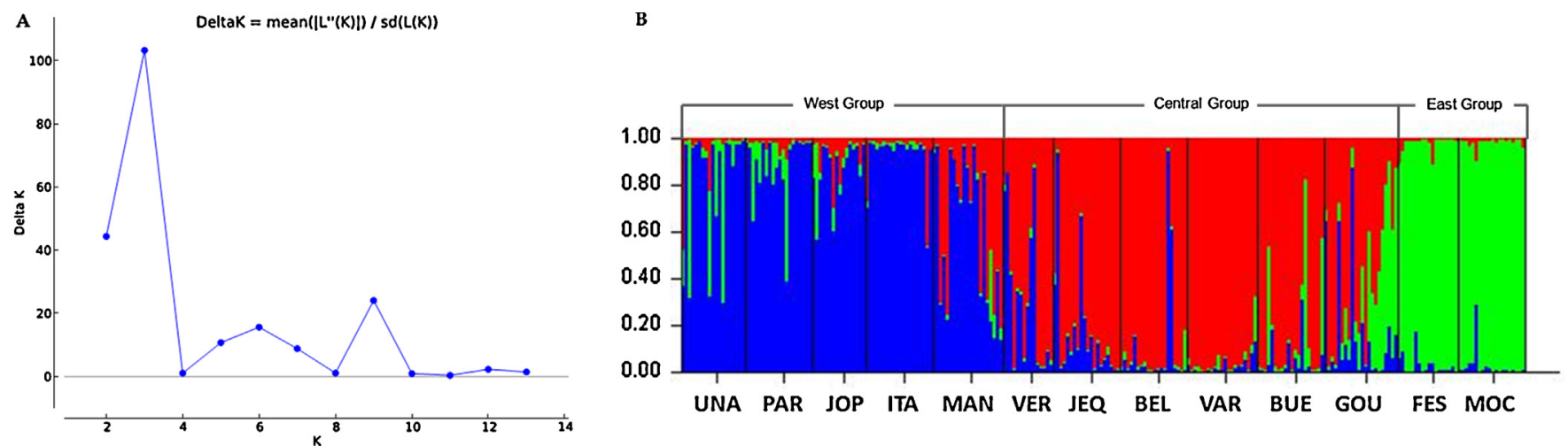

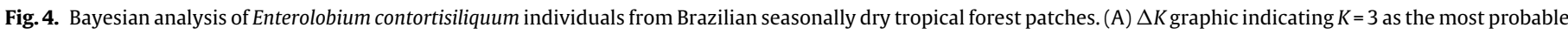
number of groups. (B) Graphic representation of the different genetic pools for $K=3$. Populations are separated by vertical bars. 
important to identify populations with high genetic diversity to indicate the operating units (OU). These units can guide effective conservation strategies for the species in situ or ex situ (Diniz-Filho and Telles, 2002; Manel et al., 2003). Besides, the other populations (JEQ, VAR, BUE, BEL, GOU, FES and MOC, mean $=0.270$ ) have lower genetic diversity than UNA, PAR and JOP. These results may be caused by fragmentation of the lower São Francisco River and by landscape features such as rivers and mountain ranges in these areas, possibly limiting the gene flow among populations (see the Discussion section).

The fixation index of $E$. contortisiliquum $\left(\Phi_{\mathrm{ST}}=0.155\right)$ was consistent with outcrossing, long-lived perennial species which have seeds dispersed through ingestion by animals (Nybom, 2004). In addition, the pairwise $\Theta^{\mathrm{B}}$ showed genetic divergence among $E$. contortisiliquum populations which is not correlated with geographic distances. The E. contortisiliquum pods can be regarded as a Neotropical anachronism whose large and indehiscent fruits were eaten by the extinct megafauna and seeds were dispersed by them Janzen (1981a,b), Janzen and Martin (1982), Guimarães et al. (2008). Thus, the extinct megafauna could have promoted extensive gene flow through seed dispersal in the past and because of this there is no isolation by distance among E. contortisiliquum populations. Rodents, such as agoutis, are probably the present-day E. contortisiliquum seed disperser and the rodents may maintain the genetic structure generated by megafauna. It was confirmed that seed dispersal by rodents is efficient and may be responsible for the Neotropical woody species persistence after Pleistocene megafauna extinctions (Jansen et al., 2012).

The UPGMA dendrogram and PCA results show that E. contortisiliquum populations were clustering into three groups that were not related to geographic distance (Figs. 2 and 3). However, these populations are spatially structured into groups distributed in the West, Central and East of the study area. The West group corresponds to populations UNA, PAR, JOP, ITA and MAN and this last population exhibited genetic admixture with the Central group, indicative of gene flow (Fig. 4B). We estimated the population Q-matrix (results not shown) which calculates the proportions of membership of each pre-defined population in each of the $K$ clusters, and MAN population represents an admixed population with $35 \%$ of ancestry from Central group. The admixture of MAN population must be responsible for the proximity of this population with the Central group observed in PCA analysis (Fig. 3). VER and JEQ populations belong to the Central group, but displayed genetic admixture with the West group. According to population Q-matrix VER and JEQ have $31 \%$ and $17 \%$, respectively, of ancestry from West group. GOU population has $16 \%$ of ancestry from West group and 27\% from the East group. It is important to observe that VER and JEQ populations are close to the West group in PCA, probably because of admixture with this group, and the most admixture population GOU is located linked all groups in PCA (Fig. 3). Finally, the East group was formed by FES and MOC populations. This genetic structure may be related with landscape. Populations of the West group, for example, are located on the left bank of the São Francisco River, which may act as a partial geographic barrier limiting gene flow. Another important geographic barrier may be the Espinhaço Range, which may have influenced the patterns observed for the East group. These possible barriers are partially consistent with the two key barriers detected using the software Barrier v.2.2 (Fig. 1). Genetic discontinuities corresponding to the Espinhaço Range were detected for two Chamaecrista species (Leguminosae) (Silva et al., 2007), Bulbophyllum exaltatum (Orchidaceae) (Ribeiro et al., 2008) and Vellozia gigantean (Velloziaceae) (Lousada et al., 2011). Besides, rivers acting as geographic barriers to gene flow were also observed for Copaifera langsdorffii (Pinto et al., 2004) and Silene tatarica (Tero et al., 2003).
The present-day deforestation caused by human activities is reducing natural habitats of $E$. contortisiliquum and represents an immediate threat to its survival. However, it was observed that the species has high genetic diversity which needs to be preserved. Only two of 13 populations analyzed in this study are located in protected areas, respectively, Mata Seca State Park (MAN) and Lapa Grande State Park (MOC). The highest rates of genetic diversity analyzed were found outside of these conservation units. We propose the creation of protected areas in different geographic regions which includes E. contortisiliquum populations from different genetic clusters.

Populations UNA, PAR and JOP are priorities because they are not in protected areas and have the highest genetic diversities. Besides, VAR is important since jointly with the protected areas (MAN and MOC) and populations cited above, the three genetic clusters will be preserved, which could maximize the retention of genetic diversity for the species. The GOU population is also priority because it is located in the extreme south of the study area and is formed by all genetic pools (see Fig. 4B) which may represent a connection between those groups, and its conservation is necessary to avoid some isolation between them. This management will preserve differences in genetic diversity which will provide the evolutionary potential for adaptation, and long-term survival in the face of environmental change. The increase in protected areas will ensure the survival of $E$. contortisiliquum species and at the same time contribute to the preservation of the threatened Brazilian SDTF remnants.

\section{Acknowledgments}

We thank Universidade Estadual de Montes Claros for logistical support during our laboratory work and F.S. Neves for field help. We gratefully acknowledge a postgraduate scholarship to P.A. Moreira from Coordenação de Aperfeiçoamento de Pessoal de Nível Superior (CAPES), the Fundação de Amparo à Pesquisa de Minas Gerais (FAPEMIG/APQ-00372-11) and Conselho Nacional de Desenvolvimento Científico e Tecnológico (CNPQ/475528/2013-1) for support. We would like to thank the two anonymous reviewers for their suggestions and comments.

\section{References}

Aguilar, R., Ashworth, L., Galetto, L., Aizen, M.A., 2006. Plant reproductive susceptibility to habitat fragmentation: review and synthesis through a metaanalysis. Ecol. Lett. 9, 968-980.

Aguilar, R., Quesada, M., Ashworth, L., Herrerias-Diego, Y., Lobo, J.A., 2008. Genetic consequences of habitat fragmentation in plant populations: susceptible signals in plant traits and methodological approaches. Mol. Ecol 17, 5177-5188.

Bonel-Raposo, J., Riet-Correa, F., Guim, T.N., Schuch, I.D., Grecco, F.N., Fernandes, C.G., 2008. Intoxicação aguda e abortos em cobaias pelas favas de Enterolobium contortisiliquum (Leg. Mimosoideae). Pesqui. Vet. Bras. 28, 593-596.

Costa, R.L.D., Marini, A., Tanaka, D., Berndt, A., Andrade, F.M.E., 2009. Um caso de intoxicação de bovinos por Enterolobium contortisiliquum (Timboril) no Brasil. Arch. Zootec. 58, 313-316.

Diniz-Filho, J.A.F., Telles, M.P.C., 2002. Spatial autocorrelation analysis and the identification of operational units for conservation in continuous populations. Conserv. Biol. 16, 924-935.

Doyle, J.J., Doyle, J.L., 1987. Isolation of plant DNA from fresh tissue. Focus 12, 13-15.

Espírito-Santo, M.M., Sevilha, A.C., Anaya, F., Barbosa, R., Fernandes, G.W., SánzhesAzofeifa, G.A., Scariot, A., Noronha, S.E., Sampaio, C.A., 2009. Sustainability of tropical dry forests: two case studies in southeastern and central Brazil. For. Ecol. Manage. 258, 922-930.

Evanno, G., Regnaut, S., Goudet, J., 2005. Detecting the number of clusters of individuals using the software STRUCTURE: a simulation study. Mol. Ecol. 14 2611-2620.

Excoffier, L., Laval, G., Schneider, S., 2005. Arlequin ver. 3.0: an integrated software package for population genetics data analysis. Evol. Bioinf. 1, 47-50, Online.

Frankie, G.W., Haber, W.A., Vinson, S.B., Bawa, K.S., Ronchi, P.S., Zamora, N., 2004 Flowering phenology and pollination systems diversity in the seasonal dry forest. In: Frankie, G.W., Mata, A., Vinson, S.B. (Eds.), Biodiversity conservation in Costa Rica: learning the lessons in a seasonal dry forest. University of California Press, Berkeley, pp. 17-29. 
Gentry, A.H., 1995. Diversity and floristic composition of neotropical dry forests. In: Bullock, S.H., Mooney, H.A., Medina, E. (Eds.), Seasonally Dry Tropical Forests. Cambridge University Press, Cambridge, pp. 146-194.

Graham, A., Dilcher, D., 1995. The Cenozoic record of tropical dry forest in northern Latin America and the southern United States. In: Bullock, S.H., Mooney, H.A., Medina, E. (Eds.), Seasonally Dry Tropical Forests. Cambridge University Press, Cambridge, pp. 124-145.

Guimarães, P.R., Galetti, M., Jordano, P., 2008. Seed dispersal Anachronisms: rethinking the fruits extinct megafauna ate. PLoS One 3, e1745

Hamrick, J.L., Apsit, V.J., 2004. Breeding structure of neotropical dry forest tree species in fragmented landscapes. In: Frankie, G.W., Mata, A., Vinson, S.B. (Eds.), Biodiversity Conservation in Costa Rica: Learning the Lessons in a Seasonal Dry Forest. University of California Press, Berkeley, CA, pp. 30-37.

Haber, W.A., Frankie, G.W., 1989. A tropical hawkmoth community: Costa Rican dry forest Shingidae. Biotropica 21, 155-172.

Holsinger, K.E., Lewis, P.O., 2005. Hickory: A Package for Analysis of Population Genetic Data v.1.0.4. Department of Ecology and Evolutionary Biology, University of Connecticut, Storrs, CT.

Holsinger, K.E., Lewis, P.O., Dey, D.K., 2002. A Bayesian approach to inferring population structure from dominant markers. Mol. Ecol. 11, 1157-1164.

Jansen, P.A., Hirsch, B.T., Emsens, W.J., Zamora-Gutierrez, V., Wikelski, M., Kays, R. 2012. Thieving rodents as substitute dispersers of megafaunal seeds. Proc. Natl. Acad. Sci. 109, 12610-12615.

Janzen, D.H., 1981a. Enterolobium cyclocarpum seed passage rate and survival in horses, Costa Rican Pleistocene seed dispersal agents. Ecology 62, 593-601.

Janzen, D.H., 1981b. Guanacaste tree seed-swallowing by Costa Rican range horses. Ecology 62, 587-592.

Janzen, D.H., 1982. Variation in average seed size and fruit seediness in a fruit crop of a Guanacaste tree (Leguminosae: Enterolobium cyclocarpum). Am. J. Bot. 69, 1169-1178.

Janzen, D.H., 1988. Management of habitat fragments in a tropical dry forest: growth. Ann. Mo. Bot. Gard. 75, 105-116.

Janzen, D.H., Martin, P.S., 1982. Neotropical anachronisms: the fruits the Gomphotheres ate. Science 215, 19-27.

Ledig, F.T., 1992. Human impacts on genetic diversity in forest ecosystems. Oikos 63, 87-108.

Legendre, P., Legendre, L., 1998. Numerical Ecology, second ed. Elsevier, Amsterdam.

Lewontin, R.C., 1972. The apportionment of human diversity. Evol. Biol. 6, 381-398.

Linhart, Y.B., Mendenhall, J.A., 1977. Pollen dispersal by hawkmoths in a Lindenia rivalis Benth. population in Belize. Biotropica 9, 143.

Lousada, J.M., Borba, E.L., Ribeiro, K.T., Ribeiro, L.C., Lovato, M.A., 2011. Genetic structure and variability of the endemic and vulnerable Vellozia gigantea (Velloziaceae) associated with the landscape in the Espinhaço Range, in southeastern Brazil: implications for conservation. Genetica 139, 431-440.

Lowe, A.J., Boshier, D., Ward, M., Bacles, C.F.E., Navarro, C., 2005. Genetic resource impacts of habitat loss and degradation; reconciling empirical evidence and predicted theory for neotropical trees. Hered 95, 255-273.

Manel, S., Schwartz, M.K., Luikart, G., Taberlet, P., 2003. Landscape genetics: combining landscape ecology and population genetics. Trends Ecol. Evol. 18, 189-197.

Manni, F., Guérard, E., Heyer, E., 2004. Geographic patterns of (Genetic, Morphologic, Linguistic) variation: how barriers can be detected using Monmonier's algorithm. Hum. Biol. 76, 173-190.

Mayle, F., 2004. Assessment of the Neotropical dry forest refugia hypothesis in the light of palaeoecological data and vegetation model simulations. J. Quat. Sci. 19, 713-720.

McCune, B., Mefford, M.J., 2011. PC-ORD: multivariate analysis of ecological data, ver. 6. MjM Software, Gleneden Beach, OR.

Miles, L., Newton, A.C., Fries, R.S., Ravilious, C., May, I., Blyth, S., Kapos, V., Gordon, J.E., 2006. A global overview of the conservation status of tropical dry forests. J. Biogeogr. 33, 491-505.

Monmonier, M.S., 1973. Maximum-difference barriers: an alternative numerical regionalization method. Geogr. Anals. 3, 245-261.

Mooney, H.A., Bullock, S.H., Medina, E., 1995. Introduction. In: Bullock, S.H., Mooney, H.A., Medina, E. (Eds.), Seasonally Dry Tropical Forests. Cambridge University Press, Cambridge, pp. 1-8.

Moreira, P.A., Fernandes, G.W., 2013. Is the São Francisco River a geographic barrier to gene flow in trees of Handroanthus ochraceus? J. Trop. Ecol. 29, 243-250.

Moreira, P.A., Fenandes, G.W., Collevatti, R.G., 2009. Fragmentation and spatial genetic structure in Tabebuia ochracea (Bignoniaceae) a seasonally dry Neotropical tree. For. Ecol. Manage. 258, 2690-2695

Nei, M., 1978. Estimation of average heterozygosity and genetic distance from a small number of individuals. Genetics 89, 583-590.

Nybom, H., 2004. Comparison off different nuclear DNA markers for estimating intraspecific genetic diversity in plants. Mol. Ecol. 13, 143-1155.

Oliveira-Filho, A.T., 2006. Catálogo das árvores nativas de Minas Gerais: mapeamento e inventário da flora nativa e dos reflorestamentos de Minas Gerais. Editora UFLA, Lavras.
Paula, C.A.A., Coulson-Thomas, V.J., Ferreira, J.G., Maza, P.K., Suzuki, E., Nakahata, A.M., Nader, H.B., Sampaio, M.U., Oliva, M.L.V., 2012. Enterolobium contortisiliquum Trypsin Inhibitor (EcTI), a plant proteinase inhibitor, decreases in vitro cell adhesion and invasion by inhibition of Src protein-focal adhesion kinase (FAK) signaling pathways. J. Biol. Chem. 287, 170-182.

Peakall, R., Smouse, P.E., 2006. GENALEX 6: genetic analysis in Excel. Population genetic software for teaching and research. Mol. Ecol. Notes 6, 288-295.

Pennington, R.T., Lewis, G.P., Ratter, J.A., 2006. An overview of the plant diversity, biogeography and conservation of neotropical savannas and seasonally dry forests. In: Pennington, R.T., Lewis, G.P., Ratter, J.A. (Eds.), Neotropical Savannas and Seasonally Dry Forests: Plant Diversity, Biogeography and Conservation. CRC Press Taylor \& Francis Group, London, pp. 1-29.

Pinto, S.I.C., Souza, A.M., Carvalho, D., 2004. Variabilidade genética por isoenzimas em populações de Copaifera langsdorffii Desf. em dois fragmentos de mata ciliar. Sci. Florestalis 65, 40-48.

Pritchard, J.K., Stephens, M., Donnelly, P., 2000. Inference of population structure using multilocus genotype data. Genet 155, 945-959.

Pritchard, J.K., Wena, X., Falush, D., 2007. Documentation for Structure Software, Ver 2.2, Available http://pritch.bsd.uchicago.edu/software (accessed 15 February 2012).

Prado, D.E., 2000. Seasonally dry forests of tropical South America: from forgotten ecosystems to a new phytogeographic unit. Edinb. J. Bot. 57, 437-461.

Prado, D.E., Gibbs, P.E., 1993. Patterns of species distributions in the dry seasonal forests of South America. Ann. Mo. Bot. Gard. 80, 902-927.

Ribeiro, P.L., Borba, E.L., Smidt, E.C., Lambert, S.M., Schnadelbach, A.S., van den Berg, C., 2008. Genetic and morphological variation in the Bulbophyllum exaltatum (Orchidaceae) complex occurring in the Brazilian 'campos rupestres': implications for taxonomy and biogeography. Plant Syst. Evol. 270, 109-137.

Rocha, O.J., Aguilar, G., 2001a. Reproductive biology of the dry forest tree Enterolobium cyclocarpum (Guanacaste) in Costa Rica: a comparison between trees left in pastures and trees in continuous forest. Am. J. Bot. 88, 1607-1614.

Rocha, O.J., Aguilar, G., 2001b. Variation in the breeding behavior of the dry forest tree Enterolobium cyclocarpum (Guanacaste) in Costa Rica. Am. J. Bot. 88, 1600-1606.

Rohlf, F.J., 2000. NTSYS-pc. Numerical Taxonomy and Multivariate Analysis System, Ver. 2.2. Exeter Software, Setauket.

Sánchez-Azofeifa, G.A., Kalacska, M., Quesada, M., Calvo-Alvarado, J.C., Nassar, J.M. Rodríguez, J.P., 2005. Need for integrated research for a sustainable future in tropical dry forests. Conserv. Biol. 19, 285-286.

Särkinen, T., Iganci, J.R.V., Linares-Palomino, R., Simon, M.F., Prado, D.E., 2011. Forgotten forests-issues and prospects in biome mapping using seasonally dry tropical forests as a case study. BMC Ecol. 11, 1-15.

Saunders, D.A., Hobbs, R.J., Margules, C.R., 1991. Biological consequences of ecosystem fragmentation: a review. Conserv. Biol. 5, 18-32.

Sevilha, A.C., Scariot, A., Noronha, S.E., 2004. Estado atual da representatividade de unidades de conservação em florestas estacionais deciduais no Brasil. In: Sociedade Brasileira de Botânica (Ed.), Biomas Florestais. Annals of the 55th Congresso Nacional de Botânica. Sociedade Brasileira de Botânica, São Paulo pp. 1-63.

Silva, R.M., Fernandes, G.W., Lovato, M.B., 2007. Genetic variation in two Chamaecrista species (Leguminosae), one endangered and narrowly distributed and another widespread in the Serra do Espinhaço. Braz. Can. J. Bot. 85 629-636.

Souza, H.A.V., Lovato, M.B., 2010. Genetic diversity and structure of the critically endangered tree Dimorphandra wilsonii and of the widespread in the Brazilian Cerrado Dimorphandra mollis: implications for conservation. Biochem. Syst. Ecol. 38, 49-56.

Steininger, M.K., Tucker, C.J., Ersts, P., Killeen, J., Villegas, Z., Hecht, S.B., 2001. Clearance and fragmentation of tropical deciduous forest in the Tierras Bajas, Santa Cruz, Bolivia. Conserv. Biol. 15, 856-866.

Templeton, A.R., Shaw, K., Routman, E., Davis, S.K., 1990. The genetic consequences of habitat fragmentation. Ann. Mo. Bot. Gard. 77, 13-27.

Tero, N., Aspi, J., Siikamäki, P., Jäkäläniemi, A., Tuomi, J., 2003. Genetic structure and gene flow in a metapopulation of an endangered plant species, Silene tatarica. Mol. Ecol. 12, 2073-2085.

Vranckx, G., Jacquemyn, H., Muys, B., Honnay, O., 2011. Meta-analysis of susceptibility of woody plants to loss of genetic diversity through habitat fragmentation. Conserv. Biol. 26, 228-237.

Willmott, A.P., Búrquez, A., 1996. The pollination of Merremia palmeri (Convolvulaceae): can hawk moths be trusted? Am. J. Bot. 83, 1050-1056.

Wu, B., Geng, S.L., Shu, B., 2012. Genetic variation and the conservation of isolated populations of Derris trifoliata (Leguminosae), a mangrove-associated vine, in southern China. Biochem. Syst. Ecol. 40, 118-125.

Yeh, F.C., Yang, R.C., Boyle, T., 1999. POPGENE Microsoft Window-based Freeware for Population Genetic Analysis: Release 1.32. University of Alberta, Edmonton, AB, Available http://www.ualberta.ca/ fyeh/popgene_download.html (accessed 14 February 2012).

Zhang, R., Zhou, Z., Du, K., 2012. Genetic diversity of natural populations of endangered Ormosia hosiei, endemic to China. Biochem. Syst. Ecol. 40, 13-18. 